\title{
Conservation and management implications of deep-sea coral and fishing effort distributions in the Northeast Pacific Ocean
}

\author{
Lance E. Morgan ${ }^{1}$, Peter Etnoyer ${ }^{2}$, Astrid J. Scholz ${ }^{3}$, Mike Mertens ${ }^{3}$, Mark Powell ${ }^{4}$ \\ ${ }^{1}$ Marine Conservation Biology Institute, 4878 Warm Springs Rd., Glen Ellen, \\ CA 95442, USA \\ (lance@mcbi.org) \\ ${ }^{2}$ Aquanautix Consulting, 3777 Griffith View Drive, Los Angeles, CA 90039, USA \\ ${ }^{3}$ Ecotrust, 721 NW Ninth Avenue, Portland, OR 97209, USA \\ ${ }^{4}$ The Ocean Conservancy, 2479 Soundview Dr. NE, Bainbridge Island, WA \\ 98110 , USA
}

\begin{abstract}
The conservation of deep-sea corals is of growing interest in the United States. A range of issues including biodiversity protection, conservation of seafloor habitats, and the role of deep-sea corals as essential fish habitat places greater significance on understanding the distributions of these corals and fishing activities. At the same time overfishing of some groundfish populations highlights the need for ecosystem-based management. Here we present records of habitat-forming deepsea corals from the United States Pacific Fishery Management Council region that we analyze in relation to differential ecological impacts of demersal fishing gears. We use an ecological footprint approach combining groundfish catch by gear type with a previously published ecological severity ranking of fishing gears.

Deep-sea corals in the Isididae, Paragorgiidae, Primnoidae, Antipathidae and Stylasteriidae families are widespread throughout their depth ranges in the Northeast Pacific, although the scleractinian families Oculinidae and Caryophylliidae are relatively rare. In this qualitative analysis, we highlight areas of relatively high coral concentration such as the West Coast continental shelf break and Monterey submarine canyon, areas that are presently relatively lightly fished but where corals are recorded. Bottom trawling gear has far and away the region's largest ecological footprint. Other gears with smaller footprints include bottom longline, pot/trap and hook and line gear. Most of these impacts seem to have occurred in areas where deep-sea corals are relatively scarce, but fishing closures to protect rockfish implemented in 2002 may have the unfortunate effect of redistributing fishing effort to areas of deep-sea coral aggregations. An ecosystem-based management approach would detect and prevent such unintended consequences of redistributing fishing effort and placing deep-sea corals in harm's way.
\end{abstract}

Keywords. Conservation, management, Octocorallia, fishing gear impact

Freiwald A, Roberts JM (eds), 2005, Cold-water Corals and Ecosystems. Springer-Verlag Berlin Heidelberg, pp 1171-1187 


\section{Introduction}

Deep-sea corals are a paraphyletic assemblage of organisms belonging to the phylum Cnidaria. Some corals are more closely related to sea anemones than other "corals" such as hydrocorals. Moreover, some species usually considered deep-sea corals can be found in shallow waters $(<200 \mathrm{~m})$. Following Etnoyer and Morgan (2003) we use the term deep-sea coral to refer to a variety of hexacoral, octocoral, and hydrocoral families living in temperate waters.

In general, deep-sea corals are a poorly documented group that are increasingly at the center of conservation concern because they are considered important habitat for commercially important fishes, as well as a wide variety of other fishes and invertebrates. On the Atlantic Coast of the United States deep-sea corals occur from Georges Bank (e.g., Paragorgia arborea), to Lophelia reefs such as the Agassiz coral hills on the Blake Plateau in the mid-latitudes of North Carolina (George 2002), to the Oculina (Oculina varicosa) banks off Florida (Reed 2002). Deepsea coral records in the Northeast Pacific date to the late 19th century (Dall 1884), but contemporary concerns such as biodiversity conservation, commercial fishery sustainability, benthic impacts of commercial fishing gears and essential fish habitat (EFH) are revitalizing interest in the distribution and abundance of habitat-forming deep-sea corals (e.g., Witherell and Coon 2001; Etnoyer and Morgan 2003).

In 1996, the United States Congress revised the Magnuson-Stevens Fishery Conservation and Management Act (MSFCMA) to include changes in the way fisheries are managed. Key additions include reducing bycatch, avoiding overfishing and identifying EFH. These measures also provide an option for decision-makers to designate habitat areas of particular concern (HAPC), as in the case of Oculina Banks off Florida - a spawning area for commercially important snappers and groupers - from trawling and other forms of fishing (Reed 2002). Proposals to protect corals with similar HAPC designations are being developed in other areas of the US Exclusive Economic Zone (EEZ). Interest in Pacific deep-sea corals is driven by declining catches of groundfish, (Ralston 1998; PMCC 1999; Fig. 1), which may rely on coral habitats at various life stages.

In January 2000, the US Secretary of Commerce declared the West Coast groundfish fisheries a federal disaster. Groundfish is a general term used for 83 species of demersal fishes that are managed by the Pacific Fishery Management Council (PFMC), which includes the Federal and state waters off California, Oregon and Washington. These species are targeted by fishermen using trawl nets, bottom longlines, pots/traps, and hook and line gears. A substantial number of managed groundfish are rockfishes in the genus Sebastes. Approximately 55 species of rockfishes are targeted by fishermen and marketed under the generic term 'red snapper' (PMCC 1999). Currently nine of the 83 managed west coast groundfish species are listed as "overfished" by NOAA Fisheries, the federal agency responsible for managing fisheries in US federal waters.

Recent management action to protect declining groundfish has closed areas along a restricted depth interval of the continental shelf from Mexico to Canada beginning in the 2002 season. Under the provisions of MSFCMA, fisheries managers are 


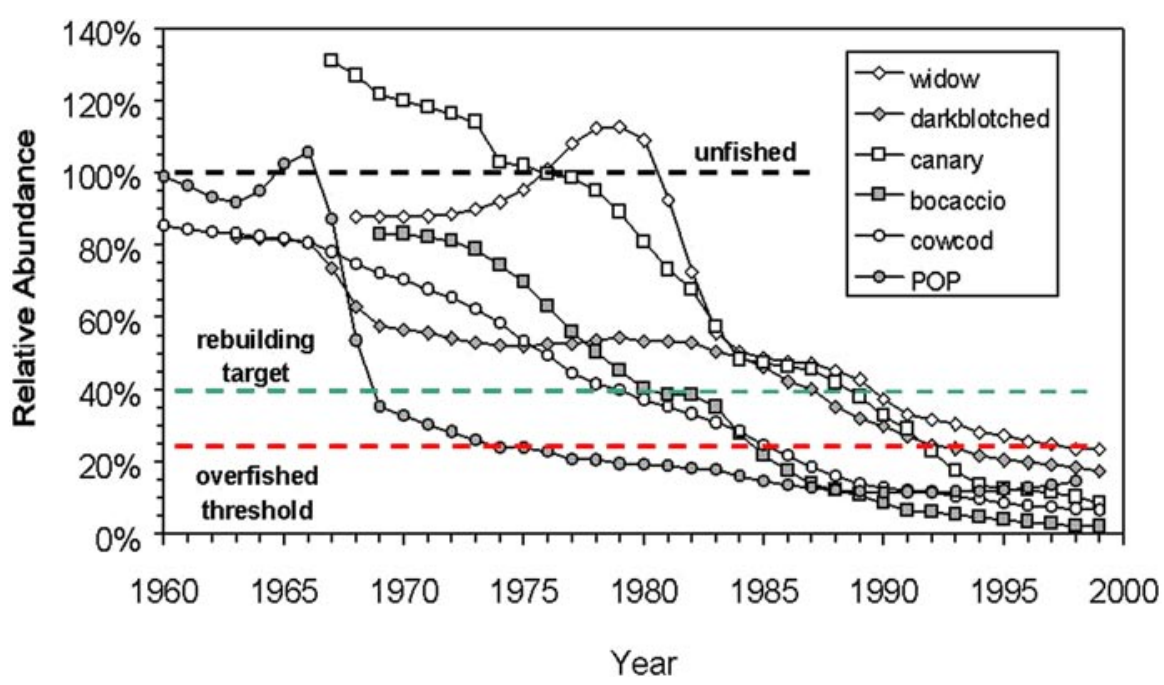

Fig. 1 Decline of six species of west coast rockfish and management thresholds (from S. Ralston pers. comm., NOAA Fisheries, based on Stock Assessments of NOAA Fisheries)

required to adopt the precautionary approach when scientific data are unavailable. In essence this means that wherever fishing poses a threat to the resource and/or the surrounding environment, precautionary measures must be taken even if the scientific results are not yet established. However, in practice the case for protection of corals from destructive fishing methods and their role as important seafloor habitat has typically been left as a "case to be made" and little precautionary action has been taken to protect them from fishing threats.

\section{Habitat value of deep-sea corals}

Several studies document that the diversity, quality and extent of bottom habitats are vital determinants of rockfish diversity, distribution and abundance (Pearcy et al. 1989; Carr 1991; O'Connell and Carlisle 1993; Nasby-Lucas et al. 2002). Additionally species richness and community composition over smaller scales also correlate with three-dimensional structure (Love et al. 1991; Krieger 1993; Yoklavich et al. 2000). Corals create extensive three-dimensional habitat that fishes use for shelter, feeding, spawning and as nursery areas for post-settlement individuals. Studies document diverse faunal associations with deep-sea corals (Heifetz 2002; Krieger and Wing 2002). Gorgonians such as red-tree coral (Primnoa spp.), which can grow as large as $7 \mathrm{~m}$ and form discrete aggregations, are now widely acknowledged as important fish habitats, and are considered EFH by the North Pacific Fishery Management Council ${ }^{1}$ (Witherell and Coon 2001). Likewise organisms that provide three-dimensional structure, such as sponge beds, are also important fish habitats (Freese 2003).

\footnotetext{
${ }^{1}$ North Pacific FMC region includes federal waters seaward of Alaska state waters.
} 
Several studies suggest commercially important fish species are found in association with deep-sea corals, such as Atka mackerel, Pleurogrammus monopterygius, and shortspine thornyhead, Sebastolobus alascanus, in Alaska (Heifetz 2002). Krieger and Wing (2002) report rockfishes as well as several other megafaunal assemblages associated with Primnoa corals in the Gulf of Alaska, and highlighted the importance of Primnoa to deep-water ecosystems. Rockfishes in Alaska, which have similar life histories to those in the PFMC region, are found in association with the same corals occurring in PFMC waters (Krieger and Wing 2002). Likewise Fosså et al. (2002) present results indicating a dense aggregation of Sebastes sp. associated with Lophelia corals off the coast of Norway. Huseb $\varnothing$ et al. (2002) found that fish in coral habitat tended to be larger than in non-coral habitat.

\section{Impact of fishing on deep-sea corals}

Deep-sea corals are considered valuable fishing areas. Historically, damage to corals from fishing was likely light to moderate as less robust gear and smaller vessels limited damage. This has changed dramatically with larger, more powerful vessels, much stronger synthetic fibers and the advent of roller and rockhopper trawl gears. With increased technology and aids to navigation including fish finders, precision depth profilers, and inexpensive geo-positioning electronics, it is much easier to target specific areas. Longlines and gillnets damage Lophelia reefs in Norway (Fosså et al. 2002). Hook and line, pot/trap and longline methods occur in and near coral areas and can lead to snagging and breaking of corals as well (Dall 1884; Breeze et al. 1997; Fosså et al. 2002). Additionally, the setting of traps on corals damages or crushes corals, and traps in set-lines are particularly damaging (Barnette 2001), especially when hauled with hydraulic winches. These modifications allow fishermen to recover gear and catch in areas that previously would have been offlimits to fishing and therefore served as natural refugia.

There is a strong emerging scientific consensus that destructive fishing is having alarming and increasing impacts on seafloors (Watling and Norse 1998; Auster and Langton 1999; Thrush et al. 2001; Dayton et al. 2002; NRC 2002; Thrush and Dayton 2002; Pew Oceans Commission 2003). Physical damage occurs to living seafloor structures (e.g., corals, sponges, seagrasses) as well as the geologic structures (e.g., boulders, cobbles, gravel, sand, mud) that serve as nursery areas, refuges, and homes for fishes and organisms living in, on or near the seafloor. The impact of mobile demersal gear, especially bottom trawling, on European deep-sea coral is a major concern (Rogers 1999; Duncan 2001). Hall-Spencer et al. (2002) document widespread trawling damage to deep-sea coral reefs at 840-1300 m depth along the West Ireland continental shelf break and at $200 \mathrm{~m}$ off West Norway. Trawling also damages deep-sea coral reefs off Norway and Tasmania (Koslow et al. 2000, 2001; Fosså et al. 2002).

In US waters, few studies evaluate the actual impacts of fishing gear on corals. Oculina coral reefs are believed to have been damaged by benthic fishing gears as long ago as the 1970's though this is not well-documented (Reed 2002). Shrimp 
trawlers have been caught illegally fishing in the reserve since its designation in 1984, and the reef is now nearly totally destroyed (Reed et al. 2005). Scleractinians are not the only vulnerable corals; Krieger and Wing (2002) document bycatch and damage to Primnoa from bottom trawls and longline gear in Alaska.

Evaluating the differential impacts of bycatch and habitat damage, and the severity of these impacts among different gear types, is a challenging task. A recent report by Morgan and Chuenpagdee (2003) reviewed over 170 documents on the bycatch and habitat impacts of ten fishing gears and provided a ranking of the ecological impacts of these gears. This report includes an experts' rating of fishing gear impacts to physical and biological habitats and five bycatch groups (i.e., shellfish and crabs, finfish, sharks, marine mammals, and seabirds and sea turtles). These ratings provided the basis for a survey of the ecological severity of the gear impacts sent to another group of experts using the 'damage schedule' approach developed by Chuenpagdee et al. (2001a, b). Their responses were combined in one overall ecological severity scale. The fishery experts considered the ecological impacts caused by bottom trawls, bottom gillnets, dredges, and midwater gillnets to be the highest, followed by moderately impacting gears: pots and traps, pelagic and bottom longlines. Finally, gears causing relatively low impacts are midwater trawls, purse seines and hook and line methods.

In this report we compare the distribution of deep-sea coral records along the West Coast of the USA, and the distribution of groundfish landings in 2000 to determine areas of potential conflict. Next we review deep-sea coral distributions in the context of recent management actions in the Pacific FMC to alleviate overfishing of groundfish. We then use the Morgan and Chuenpagdee (2003) ranking of fishing gears to develop an ecological footprint (ecological severity of gear multiplied by landings) for each gear involved in the groundfish fleet to highlight the nature of fishing threats to deep-sea corals. Finally we conclude with suggestions of appropriate policy responses.

\section{Methods}

\section{Coral occurrences}

Deep-sea coral records along the Pacific coast of the US compiled by Etnoyer and Morgan (2003) are used to examine deep-sea coral distributions (Fig. 2). These records include members of eight cnidarian families recorded in the literature and in institutional databases. Institutions include the NMFS RACEBase, California Academy of Sciences, Scripps Institution of Oceanography, Smithsonian Institution, Monterey Bay Research Institute, Santa Barbara Museum of Natural History, NOAA-Office of Exploration and one previous report (Cimberg et al. 1981). The 8 families (Caryophylliidae, Oculinidae, Antipathidae, Primnoidae, Paragorgiidae, Isididae, Coralliidae, Stylasteriidae) were chosen based on their ability to grow large enough to provide habitat for commercially important groundfish. It did not include solitary sclearactinian cup-corals, nor was it exhaustive, thus certain families such as the Paramuricidae are excluded. 


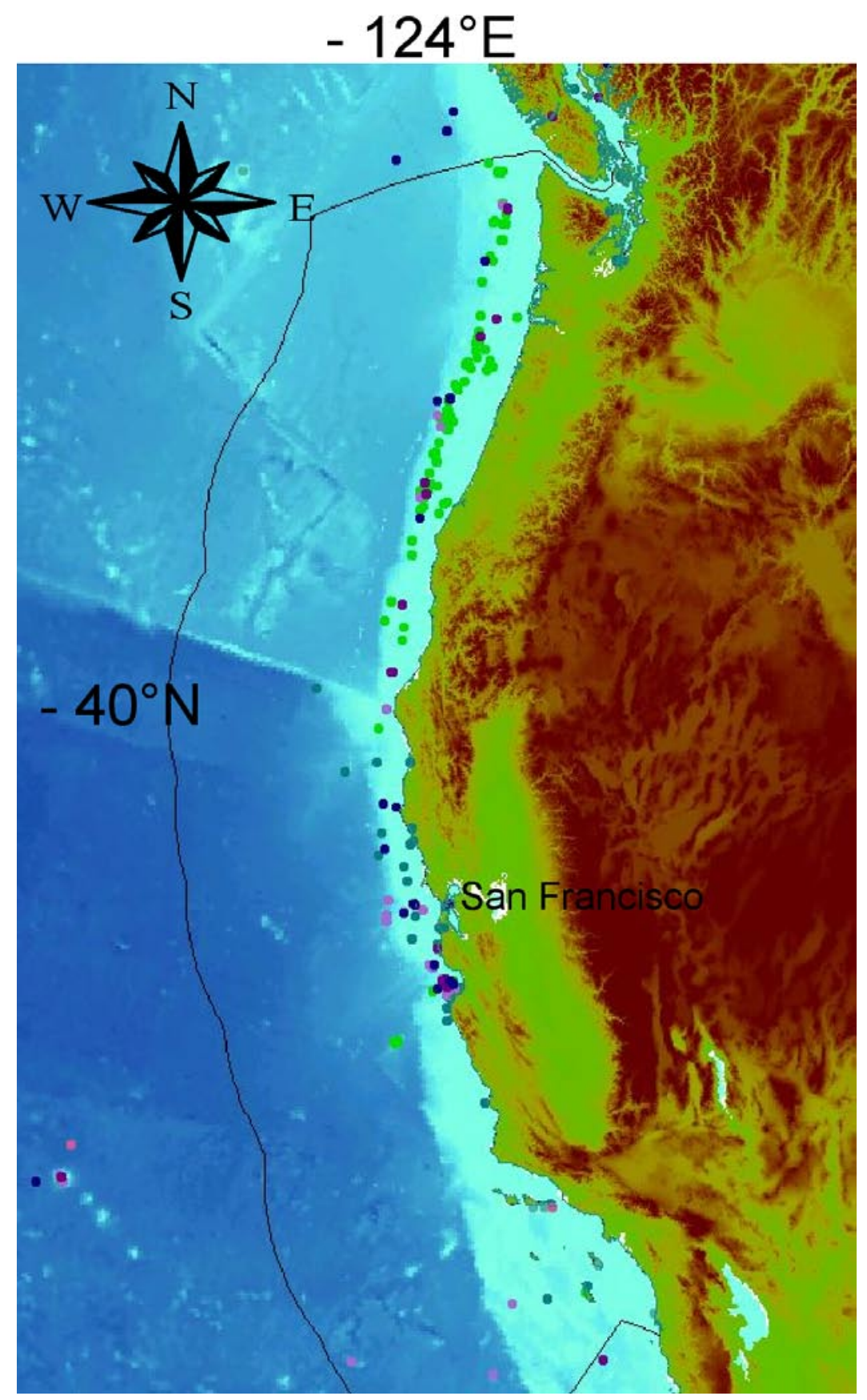

Fig. 2 Deep-sea coral records from Etnoyer and Morgan (2003). Teal - Stylasteriidae, Pink - Isididae, Purple - Paragorgiidae, Blue - Primnoidae, Green - Antipathidae. Other families are rare in the database for the U.S. West Coast 


\section{Fishing gear impacts}

A recent study ranking the differential impacts of fishing gears (Chuenpagdee et al. 2003; Morgan and Chuenpagdee 2003) is used here to establish the ecological footprint of different fishing gears used in the Pacific coast groundfish fleet (Scholz 2003; Scholz et al. 2003).

Using information from NOAA Fisheries for the year 2000, summarized by Scholz et al. (2003), we plot the distribution of four fishing gears used in the groundfish fleet (bottom trawls, bottom longlines, pots and traps and hook and line) in $9 \times 9 \mathrm{~km}$ blocks. These gears range over the three impacts levels (low, moderate and high) in Morgan and Chuenpagdee (2003) and illustrate the level of catch by these gears throughout the PFMC region. For each gear class we multiplied landings in each $9 \times 9 \mathrm{~km}$ cell by 1,2 or 3 ( $1=$ low, $2=$ moderate or $3=$ high impact $)$ to develop a scale of relative ecological impact. Landings by block were arbitrarily split into 5 classes: no landings, 1-100,000 lbs; 100,001-200,000 lbs; 200,001-300,000 lbs; and over 300,000 lbs. Together this information (impact level and landings) gives us an estimate of the ecological footprint of each of these gears for use in policy development to protect deep-sea corals and associated seafloor habitats.

\section{Results}

Antipatharian, octocorallian and hydrocorallian records are much more common than scleractinian records in the NE Pacific region. The shelf break along the coast of Washington, Oregon and northern California, and the Monterey submarine canyon edge are the areas with the largest number of records. The largest area of localized richness appears to be the Monterey Canyon. Records for Stylasteriidae tend to be the nearest to the shore, but there are also records in deeper waters. The California hydrocoral, Stylaster californicus, is common to rocky reefs and banks in California, especially banks off southern California, while other Stylasteriidae species are recorded from deeper waters. The Pacific region in general has not been extensively explored for deep-sea corals and new explorations will undoubtedly document new records and perhaps even new species. DeVogelaere et al. (2005) recently recorded Corallium sp. from Davidson Seamount, a species entirely absent from the Etnoyer and Morgan (2003) database along the US West Coast.

Plotting the deep-sea coral occurrences with the 2000 landings data in the groundfish fishery (as compiled by Scholz 2003; Scholz et al. 2003) shows that there appears to be little overlap with the groundfish fishery (Fig. 3). Areas of high coral diversity and abundance do not conflict with recent landings in the groundfish fishery. One notable exception is Monterey Canyon, where there is substantial overlap (Fig 3). In general fishing occurs on the shelf while coral records occur in deeper waters near the shelf break.

Plotting the 2002 groundfish closures (implemented by the PFMC in order to assist in the recovery of overfished rockfish populations) with coral records (Fig. 4) suggests these closures, which are restricted to the shelf, do not overlap many of the known coral occurrence records. This is true along the length of the three Pacific Coast states, with few exceptions. 
Finally by plotting fish landings ( 9 x 9 km blocks) scaled by the gear ranking (Chuenpagdee et al. 2003; Morgan and Chuenpagdee 2003) we develop an ecological footprint for each of the 4 gears in use in the groundfish fleet in 2000 (Scholz 2003; Scholz et al. 2003). This plot by fishing gear (Fig. 5) shows the relative difference

\section{Pacific West Coast}

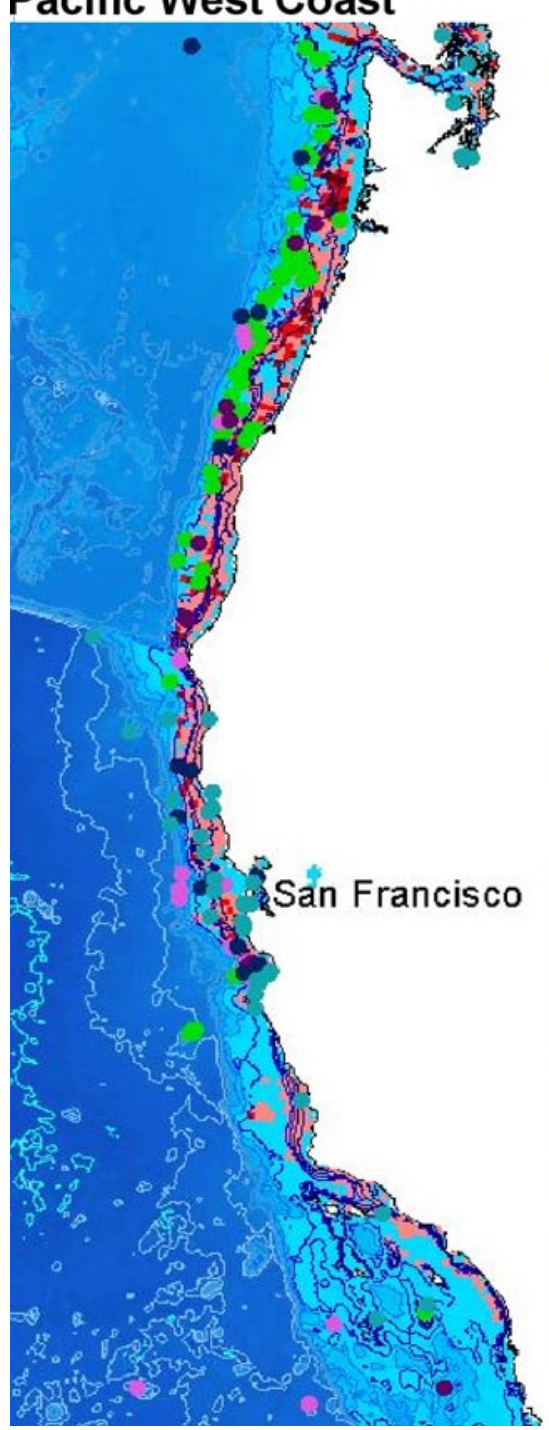

\section{Oregon Shelf}

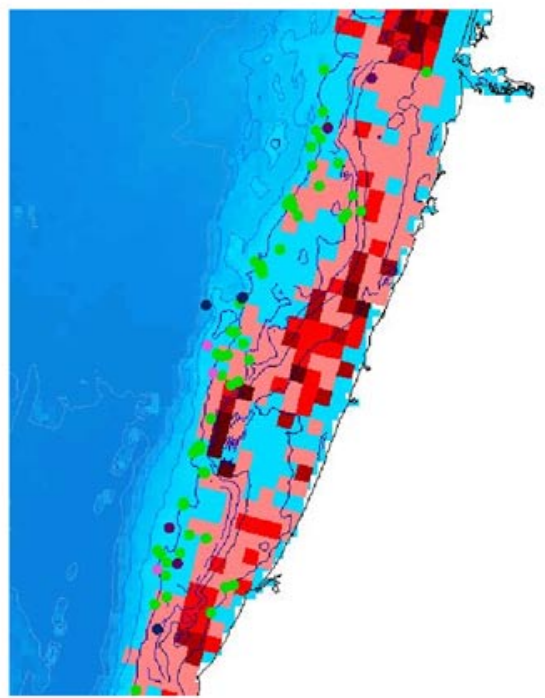

\section{Monterey Submarine Canyon}

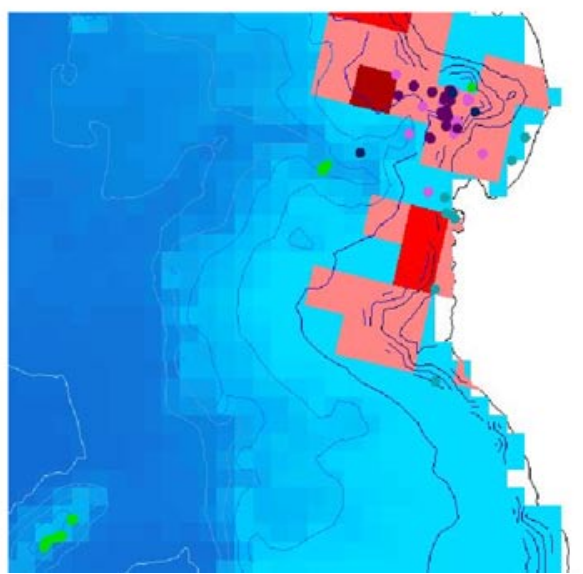

Fig. 3 Occurrences of cold-water corals and groundfish fleet catch along the Pacific west coast (left) (darker red indicates larger landings. Color code of coral records; light green - Antipathidae, teal - Stylasteriidae, pink - Isididae, purple - Paragorgiidae, dark blue Primnoidae. Oregon shelf showing abundant records along the shelf break (upper right). Monterey Canyon showing abundant and diverse records at the canyon break (lower right) 
in gear usage, as well as a severity scale (green: light impact to black: heavy impact) by the different gear types. Bottom trawl gear is the most widely used gear as well as the most ecologically severe, therefore having the largest ecological footprint.

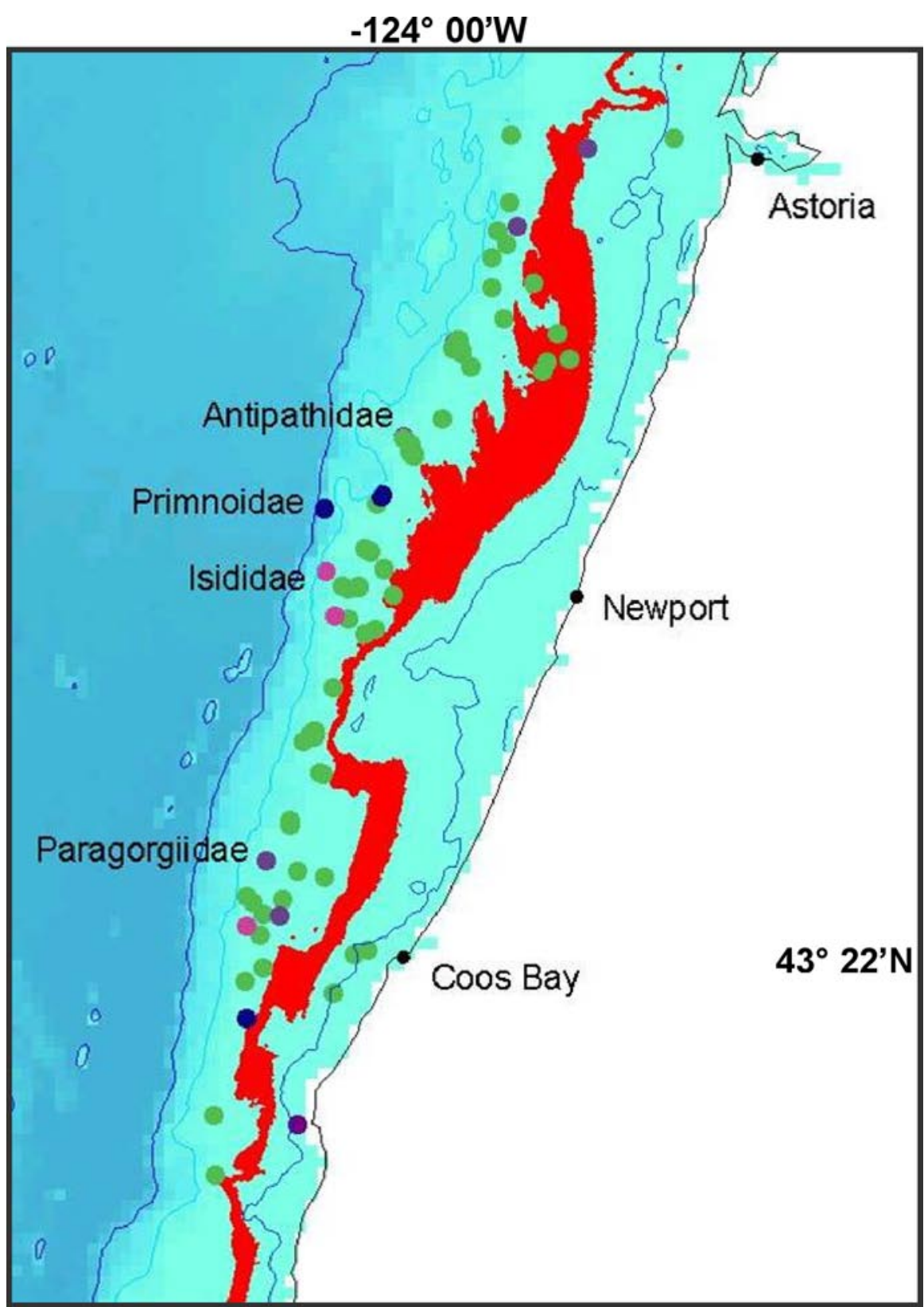

Fig. 4 Groundfish closures (red) as implemented by PFMC to protect rockfish populations. Deep-sea coral occurrences offshore of Oregon (Etnoyer and Morgan 2003) 


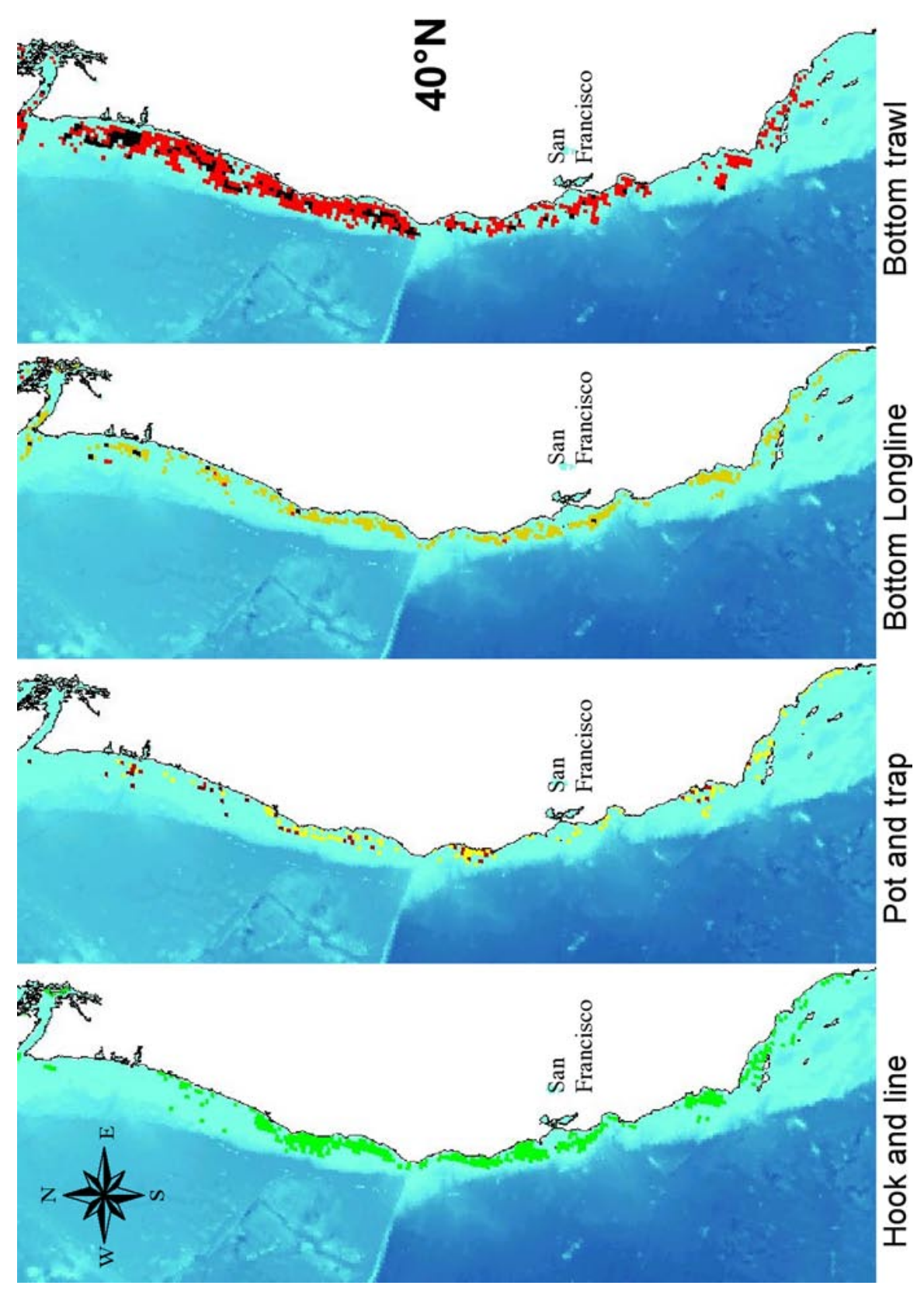

Fig. 5 Ecological footprint (landings $x$ gear ranking) for four gear types used in the Pacific Fishery Management Council region to land groundfish. Impact scale: green - light, yellow - moderate, red - heavy, black - very heavy. Landings from year 2000 see Scholz et al. (2003), gear ranking from Morgan and Chuenpagdee (2003) 
The other gears are used extensively throughout the PFMC region, but have smaller footprints.

\section{Discussion}

Our qualitative analysis of deep-sea corals shows that five of the eight coral families are widely distributed along the Pacific Coast of North America. The area of highest occurrence is the shelf break, an area of high bathymetric relief. Plots of landings in the groundfish fleet and deep-sea coral occurrences in the region managed by the Pacific Fishery Management Council show interesting patterns that may be difficult to interpret. Groundfish landings in 2000 are mostly confined to the shelf, while deep-sea coral occurrences are greatest along the continental shelf break and Monterey submarine canyon. While it is conceivable that these records reflect greater sampling intensity, especially in the Monterey Bay region, it is not likely that the shelf break has been better sampled than the shelf region. This pattern suggests that either there is limited overlap between fishery operations and deepsea corals, or that fishing has already had a substantial negative impact on coral occurrences. Since our records do not reflect historic coral distribution, it is difficult to know the impacts of past fishing.

As early as 1873, Dall reports that Stylaster corals from the Farallones Islands in northern California were entangled in fishermen's hooks and brought to the surface. Pauly (1995) refers to the erosion of our knowledge of abundance, range and distribution of species resulting from human impacts as a shifting baseline. That is, we view incremental loss as insignificant because we have no memory of the full magnitude of our impact over time frames larger than our individual history. It is possible that over 100 years of fishing and at least 30 years of trawling have impacted corals to the degree that we are no longer have an accurate picture of their distribution and abundance. Anecdotal information from fishermen in the Canadian Maritimes suggests that long-time fishermen have been well aware of these corals and have witnessed a notable decline (records from the 1800s, see Gass 2002). Given the potential ages of gorgonians - 100's to 1000's of years (Druffel et al. 1995; Andrews et al. 2002; Risk et al. 2002; Roark et al. 2003) - these species might be irrevocably harmed by a single trawl pass, and may not recover.

Fishing closures implemented in 2002 to help depleted rockfishes may have the unintended consequence of redirecting fishing effort into areas with deep-sea corals as fishermen move further offshore in search of groundfish. Further examination of this question is needed based on current data, but conventional management that is focused on maximizing catch of a few species is all too likely to make such unintended errors. Without a holistic approach such as ecosystem-based management, fishery managers will continue to witness consequences to non-target species which they are unable to predict and which results in the overall degradation of the system (see Springer et al. 2003).

Bottom trawling has the largest ecological footprint in this study (landings $\mathrm{x}$ severity of impact; Fig. 5), and is likely to move deeper in pursuit of fish (Roberts 
2002). Bottom longlines cause moderate impacts, but have a rather small overall ecological footprint because of their much more limited use in the PFMC region. Pots and traps and hook and line methods are similarly limited in impact and use in this region. Bottom longlines can damage corals (Gass 2002; Krieger and Wing 2002); longlines, like trawl nets, frequently remove coral trees from the rocks and boulders they grow upon (Krieger and Wing 2002). But bottom trawling is the most ecologically damaging method of fishing (Morgan and Chuenpagdee 2003). The benthic impacts of this mobile fishing gear has been compared to clear-cutting techniques in old growth forests (Watling and Norse 1998).

The groundfish closures on the shelf left the continental slope open to fishing, increasing the chances that fishermen might harm corals. The shelf break is important habitat for deep-sea corals (Leverette and Metaxas 2005) and fishing along the shelf break will likely have a large impact on corals. Research on rockfishes and their habitat relationships is ongoing in this region (Yoklavich et al. 2000; NasbyLucas et al. 2002), but there has been little research conducted on the associations of rockfishes and corals. The Northeast Pacific has far more species of rockfishes than elsewhere (e.g., 96 species $v s .4$ species in the North Atlantic), making it likely that at least some of these species are habitat specialists. Knowledge of habitat relationships of rockfish is increasing, but we may never understand the degree to which habitat degradation has occurred, or its impact on depleted populations. More research on these types of relationships for the various rockfish species is needed. Likewise better documentation by submersibles and ROVs is needed in areas of high rockfish catch.

\section{Management implications}

Ecosystem-based management (EBM) is our best hope for maintaining all interacting components of an ecosystem (Dayton et al. 1995; Pitcher and Pauly 1998). Conventional management goals targeting maximum sustainable yield are ill-equipped to account for deep-sea corals, as well as other seafloor habitats, in the absence of a directed fishery. Provisions for EFH and marine protected areas (MPAs) are important steps in the process of moving towards EBM, but are not sufficient. Ecosystem-based management will progress only by acknowledging differential impacts of fishing gears and by restricting certain gears to protect not just target species, but their habitats and associated species as well (i.e., deep-sea corals, other invertebrates and non-target fish species).

There is urgent need for appropriate policy responses to minimize fishing gear impacts on seafloor habitats. The severity ranking of the ten commonly used gears in the US provides a basis for formulating fisheries policies aimed at protecting corals (Chuenpagdee et al. 2003; Morgan and Chuenpagdee 2003). Fishery policies should encourage a shift from gears with higher impacts to gears with lower impacts for Pacific groundfish among the four gear types used by the groundfish fleet (Scholz 2003; Scholz et al. 2003; see Fig. 5). A good example of this "shifting gears" is the California spot prawn (Pandalus platyceros) fishery, where rockfish bycatch is 
being greatly reduced by shifting from bottom trawls to traps (Reilly and Geibel 2002). Reduced use of bottom trawls not only benefits overfished rockfish stocks, but also lessens damage to benthic habitat on which spot prawns, rockfishes and deep-sea coral species rely. Prawns caught in traps also have a higher market value because they are less damaged by fishing gear. Clearly, shifting gears pays off in the long run, as fishers can maintain high economic returns, without long-term damage to groundfish habitats. However this gear shift is initially an expensive proposition for fishermen, and incentives are one way to encourage fishers to voluntarily shift gears that is worth exploring.

Throughout the USA, fishery management councils are required to address the impacts of fishing through the National Environmental Protection Act (NEPA) by developing Environmental Impact Reports (EIR) to address the multiple impacts of fishing. Furthermore the US Magnuson-Stevens Fishery Conservation and Management Act, as reauthorized and amended in 1996 by the Sustainable Fisheries Act, mandates more attention to habitat protection, including designation of EFH and consideration of actions to conserve such habitat (Section 110). A number of actions have been taken in the USA to address habitat impacts of fishing. For example, measures to reduce habitat damage include banning of bottom trawls throughout the 1.5 million square miles of the Western Pacific Fishery Management Council (Code of Federal Regulations 2002) and closed areas for the groundfish fishery on Georges Bank in New England (Collie et al. 1997). Moreover, areas closed to trawls to reduce bycatch, such as closures aimed at reducing bycatch of red king crabs (Paralithodes camtschaticus) in federal waters off Alaska, might also have substantial benefits for other benthic species.

Proactive closures, such as MPAs aimed at the most destructive gears in the most sensitive habitats offers a robust means to protect both habitat and fishermen without the need for draconian measures such as the massive closures from Canada to Mexico as implemented in 2002 by the PFMC. Effective implementation of MPAs depends largely on the acceptance of user groups and others affected by it. Thus a fair, transparent and inclusive process in the design can facilitate implementation and can be achieved by incorporating the differences in the ways fishing gears impact marine ecosystems. The most destructive gears should be managed using appropriately stringent policies, for example, complete prohibition of use in ecologically sensitive areas, such as concentrations of deep-sea corals. One useful management measure is banning the use of roller and rockhopper gear on bottom trawls that allow fishing in these coral habitats. This is the approach taken in the Ocean Habitat Protection Act (HR 1690) legislation introduced in the $108^{\text {th }}$ U.S. Congress.

At the same time fishery management councils can provide incentives through additional catch allocations to fishermen using less destructive gears and technologies. In the Pacific Fishery Management Council's groundfish fishery, a matrix of habitat sensitivity and gear impact is one way forward in addressing catch allocation among the four groundfish gear types. The severity ranking of fishing gears suggests the need for policies that encourage shifting from high-impact gears 
to low-impact gears. Regardless of the gear, where impacts occur to threatened or endangered species or sensitive habitats, their management should be considered high priority. In cases where habitat impacts cannot be addressed by alternative fishing gears and practices, implementing closed areas will protect healthy ocean ecosystems and species (Collie et al. 1997; NRC 2002).

Of course, scientific research is essential to intelligent fishery management. We recommend more mapping research on deep-sea coral distribution and abundance and determining the degree to which coral aggregations provide EFH for groundfish in the PFMC region and beyond. Managers must also move to a more holistic appreciation of the impacts of fishing, looking not only at impacts to target species such as rockfish, but the collateral impacts to the ecosystems that support them.

\section{Acknowledgments}

We thank the many institutions that provided us with deep-sea coral records, Smithsonian Institution, California Academy of Sciences, Monterey Bay Aquarium Research Institute, NOAA Ocean Exploration Program, Scripps Institution of Oceanography, NOAA Fisheries, Santa Barbara Museum of Natural History, and REEF. We are grateful to Dr. Tom Hourigan for providing us an opportunity to begin this inquiry. Also thank member of the Pacific Fisheries Management Council staff for assistance with information. Fan Tsao, Sara Maxwell and Elliott Norse assisted in reviewing this manuscript. Additional gratitude to Ratana Chuenpagdee, Dave Canny and Michele Dailey. We thank Martin Willison and one anonymous reviewer for constructive comments. We also appreciate the many influential conversations and wonderful presentations by participants at the Second International Symposium on Deep-Sea Corals in Erlangen, Germany.

\section{References}

Andrews AH, Cordes E, Mahoney MM, Munk K, Coale KH, Cailliet GM, Heifetz J (2002) Age and growth and radiometric age validation of a deep-sea, habitat-forming gorgonian (Primnoa resedaeformis) from the Gulf of Alaska. Hydrobiologia 471: 101-110

Auster PJ, Langton RW (1999) The effects of fishing on fish habitat. In: Benaka LR (ed) Fish Habitat: Essential Fish Habitat and Rehabilitation. Amer Fish Soc Symp 20: 150-187

Barnette MC (2001) Review of fishing gear utilized within the Southeast Region and their potential impacts on essential fish habitat. NMFS-SEFSC-449. US Dept Commerce, NOAA, St. Petersburg

Breeze H, Davis DS, Butler M (1997) Distribution and status of deep sea corals off Nova Scotia. Marine Issues Comm Spec Publ 1, Ecology Action Center, Halifax

Carr MH (1991) Habitat selection and recruitment of an assemblage of temperate marine reef fishes. J Exp Mar Biol Ecol 146: 113-137

Chuenpagdee R, Knetsch JL, Brown TC (2001a) Coastal management using public judgments, importance scales, and predetermined schedule. Coast Manage 29: 253-270

Chuenpagdee R, Knetsch JL, Brown TC (2001b) Environmental damage schedule: community judgments of importance and assessments of losses. Land Econ 77: 1-11 
Chuenpagdee R, Morgan LE, Maxwell S, Norse EA, Pauly D (2003) Shifting gears: addressing the collateral impacts of fishing methods in US waters. Front Ecol Environ 9: 517-524

Cimberg RL, Gerrodette T, Muzik K (1981) Habitat requirements and expected distribution of Alaskan coral. Final Rep Res Unit 601, VTN Oregon, Inc, Rep Off Marine Poll Assess, Alaska Off, US Dept Commerce, NOAA, OCSEAP Final Rep 54: 207-308

Code of Federal Regulations (2002) Fisheries off West Coast States and in the Western Pacific: gear restrictions. Code Fed Regul 50: 461-556

Collie JS, Escanero GA, Valentine PC (1997) Effects of bottom fishing on the benthic megafauna of Georges Bank. Mar Ecol Progr Ser 35: 159-172

Dall WA (1884) On some Hydrocorallinae from Alaska and California. Proc Biol Soc Washington 2: 111-115

Dayton PK, Thrush SF, Agardy MT, Hofman RJ (1995) Environmental effects of marine fishing. Aquat Conserv 5: 205-232

Dayton PK, Thrush SF, Coleman FC (2002) Ecological effects of fishing in marine ecosystems of the United States. Arlington, VA, Pew Oceans Comm

DeVogelaere AP, Burton EJ, Trejo T, King CE, Clague DA, Tamburri MN, Caillet GM, Kochevar RE, Douros WJ (2005) Deep-sea corals and resource protection at the Davidson Seamount, California, U.S.A. In: Freiwald A, Roberts JM (eds) Cold-water Corals and Ecosystems. Springer, Berlin Heidelberg, pp 1189-1198

Duncan C (2001) Offshore marine conservation, 'Darwin Mounds' and beyond. Mar Conserv 5: $14-15$

Druffel ERM, Griffin S, Witter A, Nelson E, Southon J, Kashgarian M, Vogel J (1995) Gerardia: Bristlecone pine of the deep-sea? Geochim Cosmochim Acta 59: 5031-5036

Etnoyer P, Morgan LE (2003) Occurrences of habitat-forming, deep-sea corals in the Northeast Pacific. Final Rept NOAA Off Protected Resour

Fosså JH, Mortensen PB, Furevik DM (2002) The deep-water coral Lophelia pertusa in Norwegian waters: distribution and fishery impacts. Hydrobiologia 471: 1-12

Freese JL (2003) Trawl-induced damage to sponges observed from a research submersible. Mar Fish Rev 63: 7-13

Gass SE (2002) An assessment of the distribution and status of deep sea corals in Atlantic Canada by using both scientific and local forms of knowledge. MSc thesis, Dalhousie Univ, Halifax, Nova Scotia

George RY (2002) Ben Franklin temperate reef and deep-sea 'Agassiz Coral Hills' in the Blake Plateau off North Carolina. Hydrobiologia 471: 70-81

Hall-Spencer J, Allain V, Fosså JH (2002) Trawling damage to Northeast Atlantic ancient coral reefs. Proc R Soc London B 269: 507-511

Heifetz J (2002) Coral in Alaska: distribution, abundance, and species associations. Hydrobiologia 471: 19-28

Husebø A, Nøttestad L, Fosså JH, Furevik DM, Jørgensen SB (2002) Distribution and abundance of fish in deep-sea coral habitats. Hydrobiologia 471: 91-99

Koslow JA, Boehlert GW, Gordon JDM, Haedrich RL, Lorance P, Parin N (2000) Continental slope and deep-sea fisheries: implications for a fragile ecosystem. ICES J Mar Sci 57: 548-577

Koslow JA, Gowlet-Holmes K, Lowry JK, O'Hara T, Poore GCB, Williams A (2001) Seamount benthic macro-fauna off southern Tasmania: community structure and impacts of trawling. Mar Ecol Progr Ser 213: 111-125

Krieger KJ (1993) Distribution and abundance of rockfish determined from a submersible and by bottom trawling. Fish Bull 91: 87-96 
Krieger KJ, Wing BL (2002) Megafauna associations with deepwater corals (Primnoa spp.) in the Gulf of Alaska. Hydrobiologia 471: 82-90

Leverette T, Metaxas A (2005) Predicting habitat for two species of deep-water coral on the Canadian Atlantic continental shelf and slope. In: Freiwald A, Roberts JM (eds) Coldwater Corals and Ecosystems. Springer, Berlin Heidelberg, pp 467-479

Love MS, Carr MH, Haldorson LJ (1991) The ecology of substrate-associated juveniles of the genus Sebastes. Environ Biol Fish 30: 225-243

Morgan LE, Chuenpagdee R (2003) Shifting gears: addressing the collateral impacts of fishing methods in US waters. Pew Science Ser, Washington DC

Nasby-Lucas NM, Embley BW, Hixon MA, Merle SG, Tissot BN, Wright DJ (2002) Integration of submersible transect data and high-resolution multibeam sonar imagery for a habitat-based groundfish assessment of Heceta Bank, Oregon. Fish Bull 100: 739751

National Research Council (NRC) (2002) Effects of Trawling and Dredging on Seafloor Habitat. National Academy Press, Washington DC

O'Connell VM, Carlilse CW (1993) Habitat-specific density of adult yelloweye rockfish Sebastes ruberrimus in the eastern Gulf of Alaska. Fish Bull 91: 304-309

Pacific Marine Conservation Council (1999) Rockfish Report: The Status of West Coast Rockfish. http://www.pmcc.org/rockfishreport.html, Astoria, Oregon

Pauly D (1995) Anecdotes and the shifting baseline syndrome of fisheries. Trends Ecol Evol 10: $p p 430$

Pauly D, Christensen V, Dalsgaard J, Froese R, Torres F (2002) Towards sustainability in world fisheries. Nature 418: 689-695

Pearcy WG, Stein DL, Hixon MA, Pikitch EK, Barss WH, Starr RM (1989) Submersible observations of deep-reef fishes of Heceta Bank, Oregon. Fish Bull 87: 955-965

Pew Oceans Commission (2003) America's living oceans: charting a course for sea change. A report to the nation - recommendations for a new ocean policy. Pew Oceans Comm, Washington DC

Pitcher TJ, Pauly D (1998) Rebuilding ecosystems, not sustainability, as the proper goal of fisheries management. In: Pitcher TJ, Hart PJB, Pauly D (eds) Reinventing Fisheries Management. Chapman and Hall, London, pp 311-329

Ralston S (1998) The status of federally managed rockfish on the U.S. West Coast. In: Yoklavich M (ed) Marine harvest refugia for West Coast rockfish: a workshop. NOAA Tech Memo, NMFS-SWFSC-255

Reed J (2002) Deep-water Oculina coral reefs of Florida: biology, impacts, and management. Hydrobiologia 471: 43-55

Reed J, Shephard AN, Koenig CC, Scanlon KM, Gilmore RG (2005) Mapping, habitat characterization, and fish surveys of the deep-water Oculina coral reef Marine Protected Area: a review of historical and current research. In: Freiwald A, Roberts JM (eds) Coldwater Corals and Ecosystems. Springer, Berlin Heidelberg, pp 443-465

Reilly PN, Geibel J (2002) Results of California Department of Fish and Game Spot Prawn Trawl and Trap Fisheries Bycatch Observer Program, 2000-2001. California Dept Fish Game, Belmont

Risk MJ, Heikoop JM, Snow MG, Beukens R (2002) Lifespans and growth patterns of two deep-sea corals: Primnoa resedaeformis and Desmophyllum cristagalli. Hydrobiologia 471: 125-131

Roark EB, Guilderson T, Flood-Page S, Dunbar RB, Ingram BL (2003) Radiocarbon based age and growth rates estimates on deep-sea corals from the Pacific. Erlanger Geol Abh Sonderbd 4: 71 
Roberts CM (2002) Deep impact: the rising toll of fishing in the deep-sea. Trends Ecol Evol 17: $242-245$

Rogers AD (1999) The biology of Lophelia pertusa and other deep-water reef forming corals and impacts from human activities. Int Rev Hydrobiol 84: 315-406

Scholz AJ (2003) Groundfish fleet restructuring information and analysis project: Final Report. March 23, 2003. Pacific Marine Conserv Counc/Ecotrust. http://www.ecotrust. org/gfr

Scholz AJ, Mertens M, Sohm D, Steinback C, Bellman M (2003) Place matters: spatial tools for assessing the socioeconomic implications of marine management measures on the Pacific Coast of the United States. In: Barnes PW, Thomas J (eds) Benthic habitats and the effects of fishing. Amer Fish Soc, Symp 2002, Bethesda

Springer AM, Estes JA, van Vliet GB, Williams TM, Doak DF, Danner EM, Forney KA, Pfister B (2003) Sequential megafaunal collapse in the North Pacific Ocean: an ongoing legacy of industrial whaling? Proc Nat Acad Sci 100: 12223-12228

Thrush SF, Dayton PK (2002) Disturbance to marine benthic habitats by trawling and dredging: implications for marine biodiversity. Ann Rev Ecol Syst 33: 449-73

Thrush SF, Hewitt JE, Funnell GA, Cummings VJ, Ellis J, Schultz D, Talley D, Norkko A (2001) Fishing disturbance and marine biodiversity: the role of habitat structure in simple soft-sediment systems. Mar Ecol Progr Ser 223: 277-286

Watling L, Norse EA (1998) Disturbance of the seabed by mobile fishing gear: a comparison with forest clear-cutting. Conserv Biol 12: 1189-1197

Witherell D, Coon C (2000) Protecting gorgonian corals off Alaska from fishing impacts. Report to NPFMC. In: Willison JHM, Hall J, Gass SE, Kenchington ELR, Butler M, Doherty P (eds) Proceedings of the First International Symposium on Deep-Sea Corals. Ecology Action Centre, Nova Scotia Museum, Halifax, pp 117-125

Yoklavich MM, Greene HG, Caillet GM, Sullivan DE, Lee RN, Love MS (2000) Habitat associations of deep-water rockfishes in a submarine canyon: an example of a natural refuge. Fish Bull 98: 625-641 
